\title{
Nitrogen utilization in chlorophyll and primary productivity maximum layers: an analysis based on the f-ratio
}

\author{
W. Glen Harrison \\ Department of Fisheries and Oceans, Biological Oceanography Division, Bedford Institute of Oceanography, Box 1006, \\ Dartmouth, Nova Scotia, Canada B2Y 4A2
}

\begin{abstract}
An analysis was made of the relative importance of 'new' ( $\mathrm{NO}_{3}$ uptake) and 'regenerated' $\left(\mathrm{NH}_{4}\right.$ uptake) production in the chlorophyll maximum (CHLmax) and primary productivity maximum (PPmax) layers of 152 profiles from temperate coastal and ocean waters. In the majority of the profiles (90 of 152), the PPmax was shallower than the CHLmax. For those profiles, the magnitude of the f-ratio $\left[\mathrm{NO}_{3}\right.$ uptake/(NO $\left.3+\mathrm{NH}_{4}\right)$ uptake $]$ was statistically less at the PPmax than at the CHLmax. These results offer support to the notion that the PPmax is fuelled largely by regenerated nutrients while the CHLmax is supported by new nutrients and is consistent with published evidence that: (1) the PPmax is an important site of enhanced zooplankton grazing and nutrient regeneration, and (2) the deeper CHLmax is at least partially a manifestation of in situ algal growth associated with the nitracline.
\end{abstract}

\section{INTRODUCTION}

A common biological feature of the upper water column of stable open ocean or temperate coastal waters after the onset of thermal stratification is a vertically well-defined layering of planktonic plants and animals. This vertical structuring is generally characterized by a subsurface maximum in chlorophyll a (CHLmax), often associated with a density discontinuity or nutricline, and a corresponding maximum in zooplankton abundance or biomass (e.g. Longhurst 1976. Cullen 1982, Longhurst \& Harrison 1989). Detailed analyses of plankton profiles have revealed that the vertical positioning of the phytoplankton and zooplankton peaks often do not coincide; maximum zooplankton aggregation is frequently shallower than the depth of the CHLmax and usually associated with the maximum in absolute primary productivity (PPmax) (Longhurst 1976), or productivity normalized to biomass ( $\mathrm{P}^{\mathrm{B}} \mathrm{max}$ ) (Roman et al. 1986). Despite considerable interest in this association, a clear understanding of the presumed preference of grazers for phytoplankton in the shallower PPmax layer rather than in the more biomass-rich CHLmax has not been established, although differences in 'food quality' have been suggested (Longhurst 1976, Roman et al. 1986, Napp 1987. Napp et al. 1988a, b, Longhurst \& Harrison 1989).
One likely consequence of the aggregation of grazers in the PPmax layer is an intensification of nutrient regeneration there, from their metabolic (excretory) activity (Roman et al. 1986). Experimental evidence for enhanced grazing, respiratory activity and ammonium regeneration above the CHLmax (and coincident with the PPmax) exists for coastal and oceanic waters (Bidigare et al. 1982, King 1984, Roman et al. 1986, King et al. 1987). This localized nutrient supply mechanism, in turn, fuels and may to some extent be responsible for the maximum in productivity in an otherwise nutrientdeficient, light-sufficient mixed layer.

Valuable complementary information on the interactions of primary producers and grazers may be gained through an analysis of the forms of nitrogen available for and used in primary productivity. Dugdale \& Goering (1967) showed that primary productivity could be partitioned into 'new' and 'regenerated' production based on the form of limiting nutrient, nitrogen, used. Regenerated production is that portion fuelled by nitrogen recycled biologically in the euphotic zone, ammonium $\left(\mathrm{NH}_{4}\right)$ being the principal form. New production, on the other hand, is fuelled by external sources, primarily in the form of nitrate $\left(\mathrm{NO}_{3}\right)$ supplied principally by vertical mixing from below the euphotic zone. If the PPmax is a site of enhanced grazing (and nutrient regeneration) activity, then the relative proportion of regenerated 
production should be greater (or proportion of new production less) there than at the CHLmax, which presumbably owes its existence to a greater extent to new ( $\mathrm{NO}_{3}$-based) production (Lorenzen 1967, Anderson 1969. Venrick et al. 1973, Herbland \& Voituriez 1979, Eppley et al. 1988, Longhurst \& Harrison 1989).

With the above points in mind, I describe here an analysis of the relative importance of new and regenerated production in the PPmax and CHLmax layers from an extensive number of productivity profiles collected by our laboratory over the past several years

\section{METHODS}

Data on the depths of the nitracline ( $\mathrm{Zn}$, depth of first detectable $\mathrm{NO}_{3}$ ), the euphotic zone (Ze, $1 \%$ light level), the CHLmax and the PPmax were extracted from 152 productivity profiles representing 13 cruises and covering ocean regions from the tropics to the high Arctic (Table 1). Most of the stations were in coastal or continental shelf/borderland waters with some 25 to 30 from the open ocean. To assess the relative importance of new and regenerated production at each of the CHLmax and PPmax depth horizons, the corresponding $\mathrm{NO}_{3}$ and $\mathrm{NH}_{4}$ utilization rates were recorded and represented as the f-ratio (Eppley \& Peterson 1979, Eppley 1981), $\mathrm{f}=\left[\mathrm{NO}_{3}\right.$ uptake/( $\left.\mathrm{NO}_{3}+\mathrm{NH}_{4}\right)$ uptake $]$.

Standard methods were used in the measurements of chlorophyll a (Holm-Hansen et al. 1965), nutrients ( $\mathrm{NO}_{3}$ : Strickland \& Parsons 1972; $\mathrm{NH}_{4}$ : Solorzano 1969), and primary productivity $\left({ }^{14} \mathrm{C}\right.$ uptake: Steemann-Nielsen 1952). $\mathrm{NO}_{3}$ and $\mathrm{NH}_{4}$ uptake measurements followed the basic ${ }^{15} \mathrm{~N}$ tracer procedures outlined by Dugdale \& Goering (1967); incubation for carbon and nitrogen uptake were carried out either in situ or in 'simulated' in situ deck incubators (Table 1). Incubations ranged from 3 to $24 \mathrm{~h}$ but were in most cases for $24 \mathrm{~h}$, and ${ }^{15} \mathrm{~N}$ tracer additions ranged from 0.05 to $0.1 \mu \mathrm{M}$, approximately equivalent to the analytical detection limits for $\mathrm{NO}_{3}$ and $\mathrm{NH}_{4}$ using conventional methodology (see below). The euphotic depth was determined by secchi disk lowerings ( $1 \%$ light level $=3 \times$ secchi depth) or submersible light meter (LICOR).

The f-ratios derived from 'conventional' ${ }^{15} \mathrm{~N}$ uptake data may be subject to a number of errors (e.g. Harrison et al. 1987, Goldman 1988); major among these are currently felt to be the effects of isotope dilution on $\mathrm{NH}_{4}$ uptake and the 'pulsing effect' of the tracer addition (i.e. short-lived enhancement of uptake) on both $\mathrm{NO}_{3}$ and $\mathrm{NH}_{4}$ uptake. Significant isotope dilution will result in an underestimate in $\mathrm{NH}_{4}$ uptake and an overestimate in the $\mathrm{f}$-ratio as a consequence. Pulsing, on the other hand, will result in an orerestimate in $\mathrm{NO}_{3}$ or $\mathrm{NH}_{4}$ uptake or both and consequently the effects on the f-ratio are indeterminant. The significance of both dilution and pulsing errors presumably is greatest in the upper water column (mixed layer) where nutrient concentrations are often low or undetectable and where nutrient recycling is high. To compensate for the effects of isotope dilution, I have corrected the $\mathrm{NH}_{4}$ uptake data using the formulation of Kanda et al. (1987) and the assumption that $\mathrm{NH}_{4}$ uptake and regeneration are balanced; this seems to be a reasonable assumption based on experimental evidence (e.g. Glibert et al. 1982). Correction for pulsing effects are not as straightforward. I have, however, identified those data where this problem would most likely be important, i.e. where substrate concentrations were at or below the analytical limit of detection (ca $0.03 \mu \mathrm{M}$ for $\mathrm{NH}_{4}$, ca $0.05 \mu \mathrm{M}$ for $\mathrm{NO}_{3}$ ), and have

Table 1. Data sets

\begin{tabular}{|c|c|c|c|c|c|c|}
\hline Location & Lat. & Long. & Month & $\begin{array}{c}\text { No. of } \\
\text { stns }\end{array}$ & $\begin{array}{l}\text { No. of } \\
\text { depths }\end{array}$ & Incub. ${ }^{a}$ \\
\hline \multirow[t]{2}{*}{ Eastern Arctic } & $60-80^{\circ} \mathrm{N}$ & $56-94^{\circ} \mathrm{W}$ & Jul/Aug & 17 & 5 & SIS \\
\hline & $45-77^{\circ} \mathrm{N}$ & $58-78^{\circ} \mathrm{W}$ & Aug/Sep & 14 & 5 & SIS \\
\hline Labrador Sea & $52-56^{\circ} \mathrm{N}$ & $50-55^{\circ} \mathrm{W}$ & Jul & 9 & 8 & SIS \\
\hline Celtic Sea & $50^{\circ} \mathrm{N}$ & $07^{\circ} \mathrm{W}$ & May & 4 & 6 & IS \\
\hline \multirow[t]{2}{*}{ Grand Banks, Nfld } & $45^{\circ} \mathrm{N}$ & $50^{\circ} \mathrm{W}$ & Apr & 2 & 8 & IS \\
\hline & $45^{\circ} \mathrm{N}$ & $50^{\circ} \mathrm{W}$ & Sep & 6 & 9 & SIS \\
\hline Scotian Shelf & 41. $-45^{\circ} \mathrm{N}$ & $61-64^{\circ} \mathrm{W}$ & Apr & 15 & 5 & SIS \\
\hline Georges Bank/NW Atl. & $37-43^{\circ} \mathrm{N}$ & $65-68^{\circ} \mathrm{W}$ & Jul/Aug & 13 & 10 & SIS \\
\hline Mid Atlantic Bight & $35-40^{\circ} \mathrm{N}$ & $70-75^{\circ} \mathrm{W}$ & Aug/Sep & 6 & 6 & SIS \\
\hline NW Atlantic & $32-39^{\circ} \mathrm{N}$ & $55-65^{\circ} \mathrm{W}$ & Jun/Jul & 15 & 11 & IS \\
\hline S. California Bight & $32-34^{\circ} \mathrm{N}$ & $117-119^{\circ} \mathrm{W}$ & Mar/Jun/Dec & 37 & 6 & SIS \\
\hline Eastern Trop, Pacific & $09-10^{\circ} \mathrm{N}$ & $89-94^{\circ} \mathrm{W}$ & Mar/Apr & 4 & 11 & SIS \\
\hline Peru Upwelling & $10^{\circ} \mathrm{S}-05^{\circ} \mathrm{N}$ & $78-80^{\circ} \mathrm{W}$ & Oct/Nov & 10 & 6 & SIS \\
\hline
\end{tabular}


excluded these from the analysis where appropriate; of the 152 data pairs analysed, they represented 46 pairs, i.e. ca $30 \%$ of the total.

\section{RESULTS}

Most of the data were from temperate coastal waters, taken during late spring or summer, when the upper water column is typically stratified. The majority of the profiles were characterized by a well-developed, relatively low-nutrient mixed-layer and conspicuous subsurface CHLmax. The nitracline depth varied by region (Table 2) but was consistently shallower than the euphotic depth (Fig. 1). The CHLmax depth generally tracked that of the first detectable $\mathrm{NO}_{3}$ but on average was displayed slightly deeper, within the nutrient gradient (Table 2).

Considering all profiles, the depth of the PPmax was generally shallower than that of the CHLmax (Fig. 1). The average displacement was $14 \mathrm{~m}$ (Table 2); however, displacement tended to increase with increase in depth of the CHLmax (Fig. 1). A similar pattern was seen in the displacement in nitracline and euphotic depths with increase in transparency. For ca 1/3 (48 of 152) of the profiles, the depth of the CHLmax and PPmax were the same within the resolution of the data (average sample depth-spacing was on the order of 5 to $10 \mathrm{~m}$ ). Of the remaining profiles, almost $90 \%$ (90 of 104) showed the PPmax significantly shallower than the CHLmax (paired t-test, $p<0.001$ ) and within the upper mixed layer; the average displacement in this case was $24 \mathrm{~m}$. For the remaining 14 profiles, the PPmax depth apparently exceeded that of the CHLmax, by about $7 \mathrm{~m}$ on average.

Comparisons of $\mathrm{f}$-ratios showed the number of profiles where the f-ratio of the CHLmax exceeded that of the PPmax was about 2:1 considering all the data (Fig. 2). This relationship was essentially unchanged when the low substrate concentration samples (see 'Methods') were excluded. For the subset of profiles where the PPmax was shallower than the CHLmax, the f-ratios at the PPmax were significantly lower (t-test, $p<0.001$ ) than the corresponding f-ratios of the CHLmax 10.35 versus 0.52 on average; see also Table 2). For the subset of profiles where the depth of the PPmax exceeded that of the CHLmax, the f-ratios were statistically indistinguishable. Similar results were obtained when low substrate concentration samples were excluded from the analysis. There were a number of additional profiles (19 of 152) where the fratio at the PPmax was greater than that at the CHLmax (although the depth of the PPmax was shallower than that of the CHLmax), these 'anomalies' were often associated with unexpected vertical dis-

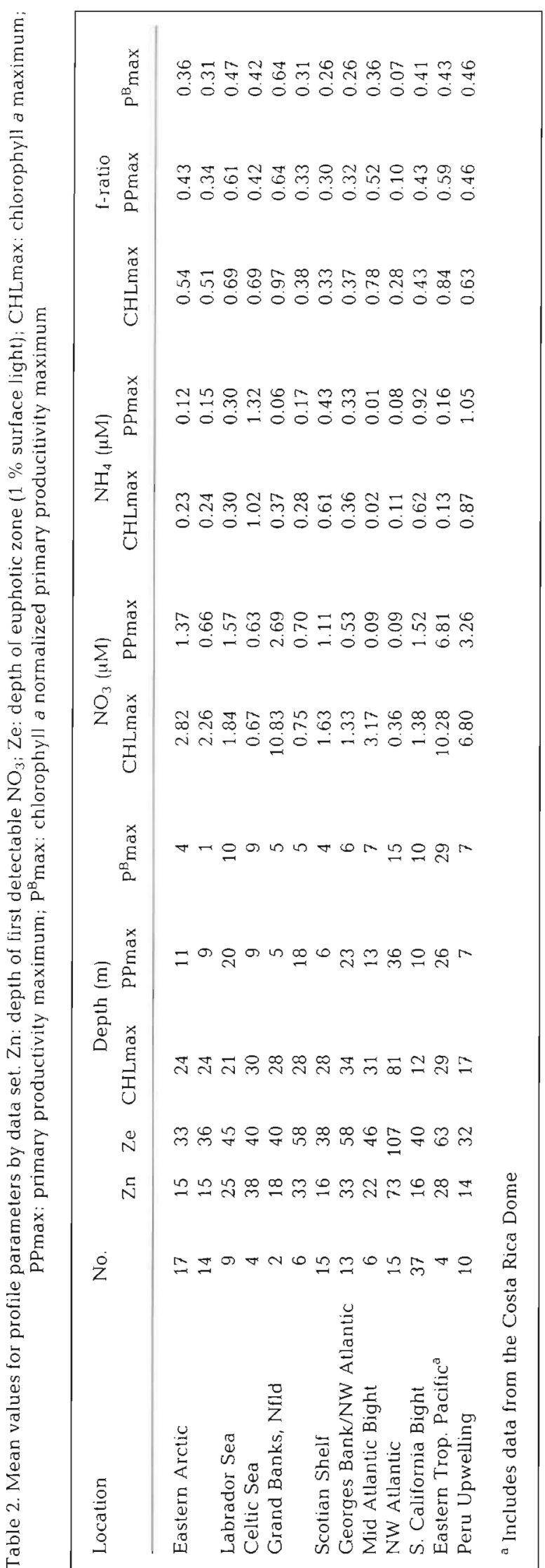



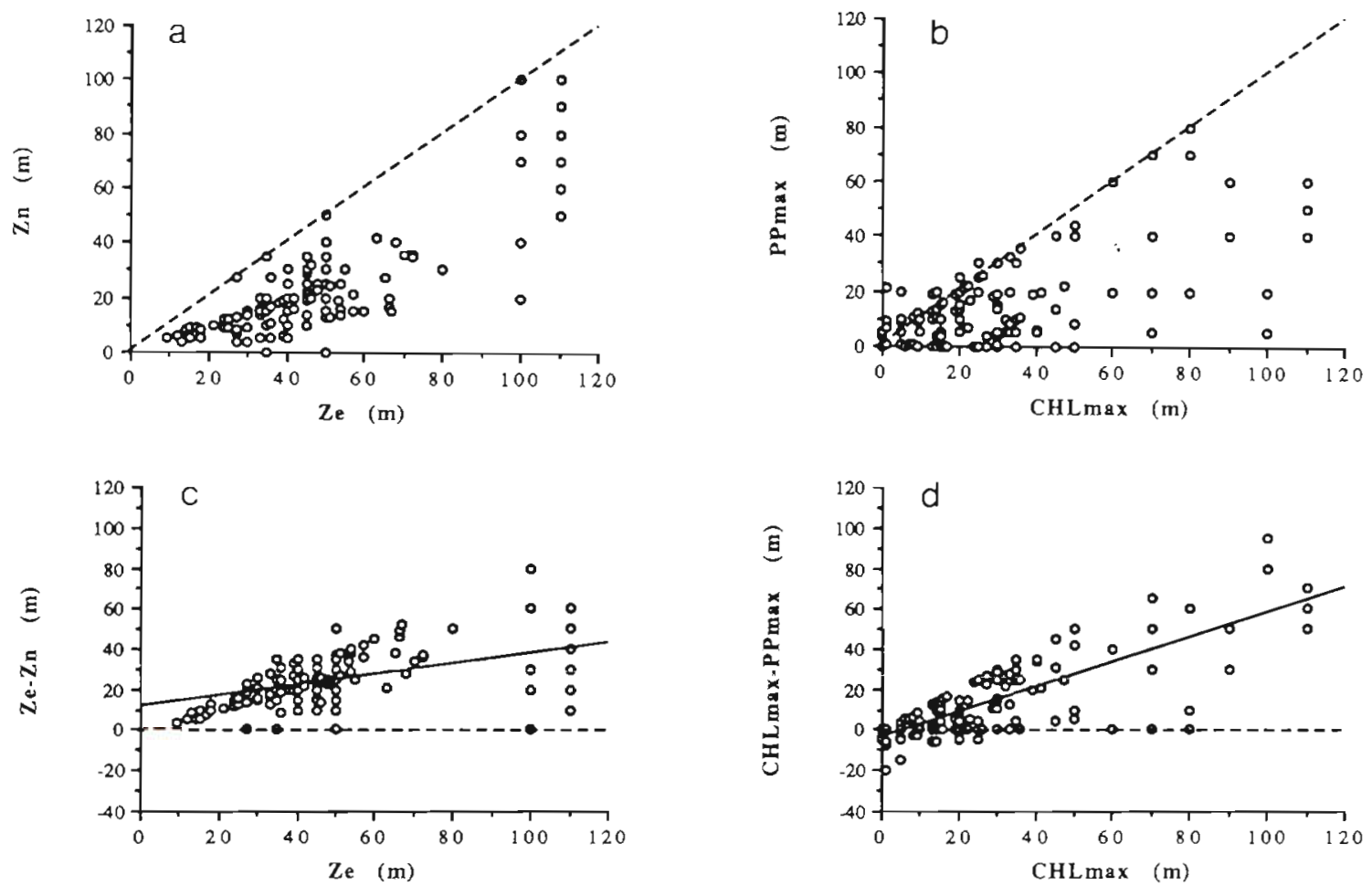

Fig. 1. Relationships among selected profile properties. (a) Depth of nitracline ( $\mathrm{Zn}$ ) versus depth of euphotic zone ( $\mathrm{Ze}$ ) (b) depth of PPmax versus depth of CHLmaxi (c) depth displacement of nitracline (Zn) and bottom of euphotic zone (Ze) versus depth of euphotic zone; (d) depth displacement of PPmax and CHLmax versus depth of CHLmax. Dashed lines in (a) and (b) denote 1:1 correspondence. Solid lines in (c) and (d) are least-squares linear regression fits

tributions of $\mathrm{NO}_{3}$, i.e. where $\mathrm{NO}_{3}$ concentrations at shallow sampling depths (PPmax) were higher than they were deeper in the water column (CHLmax).

\section{DISCUSSION}

With regard to the general structure of chlorophyll and primary productivity in stratified waters, the above

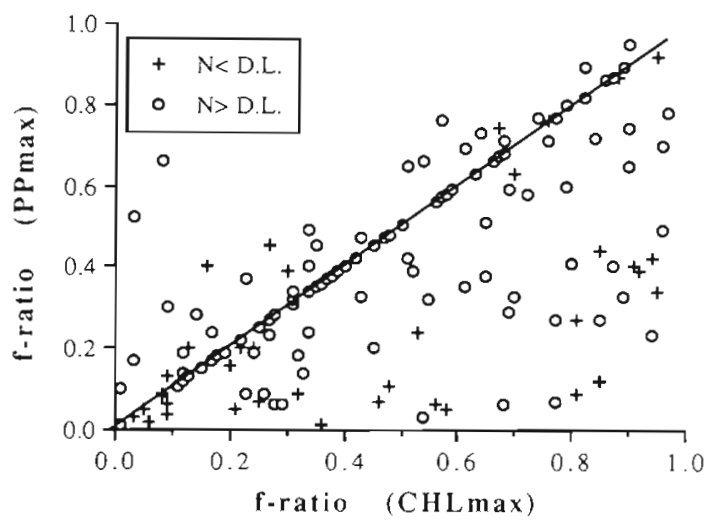

Fig. 2. Relationship between the f-ratios at the PPmax and at the CHLmax. Line denotes $1: 1$ correspondence, $\mathrm{N}>\mathrm{D} . \mathrm{L} .=$ samples where corresponding $\mathrm{NO}_{3}$ or $\mathrm{NH}_{4}$ value was greater than the analytical detection limit for that nutrient $\left(\mathrm{NO}_{3}=\right.$ $\left.0.05 \mu \mathrm{M}_{i} \mathrm{NH}_{4}=0.03 \mu \mathrm{M}\right) . \mathrm{N}<\mathrm{D} . \mathrm{L}$. = samples where $\mathrm{NO}_{3}$ or $\mathrm{NH}_{4}$ values were equal to or less than the detection limit results are not new but provide additional support for the extensive work already published on this topic (Cullen \& Eppley 1981, Cullen 1982, Napp 1987, Napp et al. 1988a, b, Longhurst \& Harrison 1989, and references cited therein). The presence of a productivity maximum shallower than the chlorophyll maximum (with depth separation increasing with depth of the CHLmax) was a common feature in coastal and oceanic waters. There were, however, a significant number of profiles (ca 1/3) in which the PPmax and CHLmax were found at the same depth. Some of these were profiles from weakly or unstratified waters (e.g. Peru upwelling region) or early in the growth season of temperate coastal waters when the CHLmax and PPmax are more likely to occur nearer the surface and at similar depths (Steele \& Yentsch 1960) Herbland \& Voituriez (1979), on the other hand, have suggested that the CHLmax, PPmax and nitracline occur at the same depth over an extensive area of the highly stratified tropical Atlantic in summer, in contrast to what has been found in the Pacific (Longhurst 1976). Profiles from the present study for the oligotrophic NW Atlantic, though less extensive than the above studies, consistently showed the PPmax to be ca $40 \mathrm{~m}$ shoaler than the CHLmax and nitracline (see also Longhurst \& Harrison 1989).

It is important to note, as others have (Napp 1987), that the depths of the true maxima in chlorophyll and 
productivity may not have coincided exactly with the discrete sampling depths chosen. This is particularly a concern for those data sets where only 5 or 6 depths (103 of 152 profiles) were available and may to some extent help explain the 'anomalous' profiles where the depth of the PPmax apparently exceeded that of the CHLmax. The general relationships seen here do not seem, however, to be at variance with those of others who have made more detailed studies of PPmax and CHLmax layers (Longhurst 1976, Cullen 1982, Napp 1987, and references therein).

The f-ratio analysis provided an additional perspective to explain the observed depth displacement of the CHLmax and PPmax in stratified waters. Although predictable depth variations in the f-ratio are well documented, results described here represent the first systematic analysis that directly addresses the hypothesis that the principal forms of nitrogen utilized within (and sources available to) the PPmax and CHLmax layers differ. The relatively lower f-ratios at the PPmax support the view that regenerated nutrients are of greater importance in maintaining the primary productivity maximum than in maintaining the subsurface biomass maximum (CHLmax). The lower f-ratios at the PPmax are consistent with observations of zooplankton aggregation (Longhurst 1976, Herman et al. 1981, Fiedler 1983, Herman \& Platt 1983, Herman 1984. Roman et al. 1986) and correspondingly elevated plankton grazing (Roman et al. 1986), respiration and $\mathrm{NH}_{4}$ excretion (Bidigare et al. 1982, King 1984, King et al. 1987) at depths shallower than the CHLmax. Roman et al. (1986) suggested that the zooplankton maximum may be centered on the biomass-specific productivity peak ( $\mathrm{P}^{\mathrm{B}}$ max) rather than the absolute PPmax, a consequence of reducing algal biomass (CHL) by grazing while enhancing primary productivity by the concommitant excretion of nutrients. In the data summarized here, the displacement between the $\mathrm{P}^{\mathrm{B}} \max$ and the CHLmax was greater and the difference in the f-ratios larger than in the PPmax-CHLmax comparison (Table 2), further supporting the contention that the grazing and accompanying nutrient regeneration activity of the zooplankton, whether aggregated at the PPmax or $\mathrm{P}^{\mathrm{B}}$ max, supply most of the nutrients to support the primary productivity there.

It is also true that microheterotrophs regenerate nutrients and their contribution may often exceed that of the macrozooplankton (Harrison 1978, 1980, Glibert 1982, Glibert et al. 1982, Harrison et al. 1983, Probyn 1987). Their distribution and metabolic activity (including nutrient regeneration), indeed, have also been observed in many cases to be maximal above the CHLmax and presumably in the region of the PPmax (Harrison et al. 1983, Ducklow 1984, Eppley et al. 1988).
Although the observed f-ratios were generally lower at the PPmax than at the CHLmax, in terms of absolute values, almost $40 \%$ on average of the primary production in the mixed layer was 'new' production. This is not surprising for coastal waters; however, f-ratios were 0.10 or less (i.e. new production $10 \%$ of total) at the oceanic stations studied (Table 2), consistent with the general pattern observed by others (e.g. Eppley \& Peterson 1979).

With regard to the question of the formation and maintenance of the CHLmax (e.g. Cullen 1982), the results of the f-ratio analysis also lends support to the view that the CHLmax is largely a 'nutrient trap' (i.e. for the upward diffusion of $\mathrm{NO}_{3}$ into the mixed layer) and may be at least partially the manifestation of in situ growth regulated by the supply rate of this 'new' nitrogen (Anderson 1969, Venrick et al. 1973, Fasham et al. 1985, Eppley et al. 1988, Longhurst \& Harrison 1989). This is also consistent with Dugdale \& Goering's (1967) conceptual model that net synthesis of plant material (in this case CHL production) occurs at the expense of 'new' nutrients (i.e. $\mathrm{NO}_{3}$ ), made available principally by vertical mixing in the region of the nitracline. This interpretation, however, requires that $\mathrm{CHL}$ is a reliable index of biomass; the CHLmax, for example can be simply a manifestation of photoadaption (more CHL cell $^{-1}$ ) rather than a true reflection of biomass (Cullen 1982).

Although Dugdale \& Goering's model of a 2-layered upper ocean may be an over-simplification, particularly for the dynamic coastal ocean, the results presented here are entirely consistent with the ideas embodied in that model - that the vertical ordering of phytoplankton communities and their metabolic activities are dependent to a large extent on the balance in the vertical between physically and biologically mediated supply of limiting nutrients (Longhurst \& Harrison 1989).

Acknowledgements. B. Irwin provided technical assistance, L. Wood, J. Spry, and A. Dessurealt helped with ${ }^{15} \mathrm{~N}$ analyses. Drs T. Platt, W. Li, A. Longhurst, J. Cullen and others provided helpful comments on an earlier version of this manuscript. I also thank Dr R. Eppley for access to his Southern California Bight data.

\section{LITERATURE CITED}

Anderson, G. C. (1969). Subsurface chlorophyll maximum in the northeast Pacific Ocean. Limnol. Oceanogr. 14: 386-391

Bidigare, B. R., King, F. D., Biggs, D. C. (1982). Glutamate dehydrogenase (GDH) and respiratory electron-transportsystem (ETS) activities in Gulf of Mexico zooplankton. J. Plankton Res. 4: 895-911

Cullen, J. J. (1982). The deep chlorophyll maximum: comparing vertical profiles of chlorophyll a. Can. J. Fish. Aquat. Sci. 39: 791-803 
Cullen, J. J., Eppley, R. W (1981). Chlorophyll maximum layers of the Southern California Bight and possible mechanisms of their formation and maintenance. Oceanologica Acta 4: 23-32

Ducklow, H. W. (1984). Geographical ecology of marine bacteria: physical and biological variability at the mesoscale. In: Klug, M. J., Reddy, C. A. (eds.) Current perspectives in microbial ecology. Am. Soc. Microbiol, Washington, D.C., p. 22-31

Dugdale, R. C., Goering, J. J. (1967). Uptake of new and regenerated forms of nitrogen in primary productivity. Limnol. Oceanogr. 12: 196-206

Eppley, R. W (1981). Autotrophic production of particulate matter. In: Longhurst, A. R. (ed.) Analysis of marine ecosystems. Academic Press, London, p. 342-361

Eppley, R. W., Peterson, B. J. (1979). Particulate organic matter flux and planktonic new production in the deep ocean. Nature, Lond. 282: 677-680

Eppley, R. W., Swift, E., Redalje, D. G., Landry, M. R., Haas, L. W. (1988). Subsurface chlorophyll maximum in AugustSeptember 1985 in the CLIMAX area of the North Pacific. Mar. Ecol. Prog. Ser. 42: 289-301

Fasham, M. J. R., Platt, T., Irwin, B., Jones, K. (1985). Factors affecting the spatial pattern of the deep chlorophyll maximum in the region of the Azores front. Prog. Oceanogr. 14 : $129-165$

Fiedler, P. C. (1983). Fine-scale spatial patterns in the coastal epiplankton off Southern California. J. Plankton Res. 5: 671-696

Glibert, P. M. (1982). Regional studies of daily, seasonal and size fraction variability in ammonium remineralization. Mar. Biol. 70: 209-222

Glibert, P. M., Lipschultz, F., McCarthy, J. J., Altabet, M. A. (1982). Isotope dilution models of uptake and reminenralization of ammonium by plankton. Limnol. Oceanogr. 27 : $639-650$

Goldman, J. C. (1988). Spatial and temporal discontinuities of biological processes in pelagic surface waters. In: Rothschild, B. (ed.) Towards a theory on biological-physical interactions in the ocean. Kluwer Academic Publishers, Dordrecht, p. 273-296

Harrison, W. G. (1978). Experimental measurements of nitrogen remineralization in coastal waters. Limnol. Oceanogr 23: $684-694$

Harrison, W. G. (1980). Nutrient regeneration and primary production in the sea. In: Falkowski, P. G. (ed.) Primary productivity in the sea. Plenum Press, New York, p. $433-460$

Harrison, W. G., Douglas, D., Falkowski, P., Rowe, G., Vidal, J. (1983). Summer nutrient dynamics of the middle Atlantic Bight: nitrogen uptake and regeneration. J. Plankton Res. 5: $539-556$

Harrison, W G., Platt, T., Lewis, M. R. (1987). f-Ratio and its relationship to ambient nitrate concentration in coastal waters. J. Plankton Res. 9: 235-248

Herbland, A., Voituriez, B. (1979). Hydrological structure analysis for estimating the primary production in the tropical Atlantic Ocean. J. mar. Res. 37: 87-101

Herman, A. W (1984). Vertical copepod aggregations and interactions with chlorophyll and production on the Peru shelf. Cont. Shelf Res. 3: 131-146

This article was presented by Dr M.R. Lewis, Washington, D.C., USA
Herman, A. W., Platt, T (1983). Numerical modelling of diel carbon production and zooplankton grazing on the Scotian shelf based on observational data. Ecol. Model. 18: 55-72

Herman, A. W., Sameoto, D. D., Longhurst, A. R. (1981). Vertical and horizontal distribution patterns of copepods near the shelf break south of Nova Scotia. Can. J. Fish. Aquat. Sci 38: 1065-1076

Holm-Hansen, O., Lorenzen, C. J., Holmes, R. W., Strickland J. D. H. (1965). Fluorimetric determination of chlorophyll. J. Cons. int. Explor Mer 30: 3-15

Kanda, J., Laws, E. A., Saino, T., Hattori, A. (1987). An evaluation of isotope dilution effect from conventional data sets of ${ }^{15} \mathrm{~N}$ uptake experiments. J. Plankton Res. 9: 79-90

King. F. D. (1984). Vertical distribution of zooplankton glutamate dehydrogenase in relation to chlorophyll in the vicinity of the Nantucket Shoals. Mar. Biol. 79: 249-256

King, F. D., Cucci, T. L., Townsend, D. W. (1987). Microzooplankton and macrozooplankton glutamate dehydrogenase as indices of the relative contribution of these fractions to ammonium regeneration in the Gulf of Maine. J. Plankton Res. 9: 277-289

Longhurst, A. R. (1976). Interactions between zooplankton and phytoplankton profiles in the eastern tropical Pacitic Ocean. Deep Sea Res. 23: 729-754

Longhurst, A. R., Harrison, W. G. (1989). The biological pump: protiles of plankton production and consumption in the upper ocean. Prog. Oceanogr 22: 47-123

Lorenzen, C. J. (1967). Vertical distribution of chlorophyll and phaeopigments: Baja California. Deep Sea Res. 14: 735-745

Napp, J. M. (1987). Primary productivity maxima in the Southern California Bight: distribution, predicted depth and nutritional content. Oceanologica Acta. 10: 329-337

Napp, J. M., Brooks, E. R., Reid, F. M. H., Matrai, P. Mullin, M. M. (1988a). Vertical distribution of marine particles and grazers. I. Vertical distribution of food quality and quantity. Mar. Ecol. Prog. Ser. 50: 45-58

Napp, J. M., Brooks, E. R., Matrai, P., Mullin, M. M. (1988b). Vertical distribution of marine particles and grazers. It. Relation of grazer distribution to food quality and quantity. Mar. Ecol. Prog. Ser. 50: 59-72

Probyn, T. A. (1987). Ammonium regeneration by microplankton in an upwelling environment. Mar. Ecol. Prog. Ser. 37. 53-64

Roman, M. R., Yentsch, C. S., Gauzens, A. L., Phinney, D. A. (1986). Grazer control of the fine-scale distribution of phytoplankton in warm-core Gulf Stream rings. J. mar Res. 44: 795-813

Solorzano, L. (1969). Determination of ammonium in natural waters by the phenolhypochlorite method. Limnol. Oceanogr. 14: 799-801

Strickland, J. D. H., Parsons, T R. (1972). A practical handbook of seawater analysis. Bull. Fish. Res. Bd Can. 167

Steele, J. H., Yentsch, C. S. (1960). The vertical distribution of chlorophyll. J. mar. biol. Ass. U.K. 39: 217-226

Steemann-Nielsen, E. (1952). The use of radioactive carbon $\left({ }^{14} \mathrm{C}\right)$ for measuring organic production in the sea. J. Cons. int. Explor. Mer 18: 117-140

Venrick, E. L., McGowan, J. A., Mantyla, A. W (1973). Deep maxima of photosynthetic chlorophyll in the Pacific Ocean. Fish. Bull. U.S. 71: 41-52

Manuscript first received: June 19, 1989

Revised version accepted: October 16, 1989 